\title{
Complete prevention of HTLV-1 infection in humanized mice (hu-PBL SCID) by a neutralizing monoclonal antibody to envelope gp46
}

\author{
Mineki Saito ${ }^{1,2^{*}}$, Reiko Tanaka', Akira Kodama', Yuetsu Tanaka ${ }^{1}$ \\ From 16th International Conference on Human Retroviruses: HTLV and Related Viruses \\ Montreal, Canada. 26-30 June 2013
}

Human T-cell leukemia virus type 1 (HTLV-1) causes both neoplastic and inflammatory diseases: adult $\mathrm{T}$-cell leukemia (ATL) and HTLV-1-associated myelopathy/ tropical spastic paraparesis (HAM/TSP). Since these disabling and/or life threatening diseases are not yet curable, it is important to prevent new infections. In this study, we have established a simple humanized mouse model of HTLV-1 infection for evaluating therapeutic and immunomodulatory interventions. Using this model, we tested the effect of HTLV-1 specific neutralizing antibodies. HTLV-1-negative normal human peripheral blood mononuclear cells (PBMCs) were transplanted directly into the spleens of severely immunodeficient mice (NOD/SCID/ $\gamma$ Cnull: NOG) together with the mitomycin-treated HTLV-1 producing T cells (ILT-M1). Before (one hour) and after (24 hours) transplantation of human PBMCs, monoclonal antibodies against HTLV-1 as well as human IgG isolated from both HTLV-1 infected and non-infected individuals were inoculated intraperitonealy. On day 14, human PBMCs were isolated from mouse spleen, and tested for HTLV1 infection by real time PCR and flow cytometry. Similar to the naturally HTLV-1 infected PBMCs, both CD4+ and $\mathrm{CD} 8+\mathrm{T}$ cells isolated from untreated or isotype antibody treated mice were found to be HTLV-1 infected, and the CD8+ T cells harbored HTLV-1 to a lesser extent. Also, HTLV-1 Tax expression was negative in isolated human PBMCs but became positive after 16 hours of culture. Although non-neutralizing monoclonal antibodies to gp46, monoclonal antibody to gag p19, and normal human IgG did not block the infection, neutralizing monoclonal antibody to gp46 and human

'Department of Immunology, Graduate School of Medicine, University of the Ryukyus, Okinawa, Japan

Full list of author information is available at the end of the article
anti-HTLV-1 IgG completely blocked the infection. Our findings provide a new strategy for preventing initial HTLV-1 infection and blocking further spread in vivo. The potential mechanisms involved in the antibody effect will also be discussed.

\section{Authors' details}

'Department of Immunology, Graduate School of Medicine, University of the Ryukyus, Okinawa, Japan. ${ }^{2}$ Department of Microbiology, Kawasaki Medical School, Kurashiki, Japan.

Published: 7 January 2014

doi:10.1186/1742-4690-11-S1-O9

Cite this article as: Saito et al: Complete prevention of HTLV-1 infection in humanized mice (hu-PBL SCID) by a neutralizing monoclonal antibody to envelope gp46. Retrovirology 2014 11(Suppl 1):09.

\section{Submit your next manuscript to BioMed Central and take full advantage of: \\ - Convenient online submission \\ - Thorough peer review \\ - No space constraints or color figure charges \\ - Immediate publication on acceptance \\ - Inclusion in PubMed, CAS, Scopus and Google Scholar \\ - Research which is freely available for redistribution \\ Submit your manuscript at www.biomedcentral.com/submit}

